\title{
On the biology and food of small-sized fish from North and Baltic Sea areas. IV. Investigations on an eulittoral mud flat at Sylt Island
}

\author{
C Dieter Zander \& Eike Hartwig \\ Zoologisches Institut und Zoologisches Museum; \\ Martin-Luther-King-Platz 3, D-2000 Hamburg 13, Federal Republic of Germany
}

\begin{abstract}
The fish fauna of an eulittoral mud flat was investigated at Sylt Island (North Sea) with special regard to its food uptake. During the course of a year the following species were caught: Pomatoschistus microps, Anguilla anguilla (elvers), Zoarces viviparus, and Gasterosteus aculeatus. Considering the potentially available food, the most abundant organisms of the benthos were harpacticoids and nematodes, whereas in the phytal layer gastropods and gammarids were dominant. The benthic biomass was found to be greatest in spring, while phytal organisms were most abundant in late summer. The greatest fish density was stated in September 1974 though only $P$. microps was present. The fish biomass was highest in spring when the elvers appeared. The main food of $P$. microps was epibenthos; in the diet of $A$. anguilla phytal organisms dominated over epibenthos, in G. aculeatus suprabenthic organisms were also present. The most prominent food component by biomass was gammarids in all investigated fish, whereas harpacticoids were only dominant in number. During the course of the year the biomass of ingested food yielded highest values in summer and autumn, but lowest in winter. A very great predatory activity was found in September 1974, which possibly caused a grazing effect on harpacticoids. An estimation of the turnover rate of small-sized fish in this month led to a value of $70 \mathrm{mg}$ dry weight $\mathrm{m}^{-2} \cdot \mathrm{d}^{-1}$.
\end{abstract}

\section{INTRODUCTION}

Marine mud flats are ecosystems which are characterized by high productivities. Their importance as nurseries for commercial fish and habitats for small-sized fish is generally acknowledged. They are extreme biotopes which are strongly affected by the tides. During low tide the organisms are exposed to the influence of air temperature, changing water levels and, in case of rain or solar radiation, to strongly changing salinities in the remaining mud puddles. These climatic conditions favour the existence of a very specialized fauna and flora which is relatively poor in species but rich in individuals.

Young and small-sized fish play a role in the turnover rate of mud flats since they are used as food by predatory fish and birds. Therefore, it is the aim of this investigation to assess the importance of small-sized fish as links in the food web of a marine mud flat. The upper eulittoral zone of the Keitum mud flat on Sylt Island (Federal Republic of Germany, North Friesian coast) appeared well suited for studies of this type. In previous 
papers (Zander, 1979a, 1979b; Hennig \& Zander, 1981) only the total biomass ingested by the caught fish was calculated here the density of fish per unit area could be counted. This method gave a better estimate of productivity and turnover rate in mud flats.

\section{MATERIAL AND METHODS}

The samples were taken every two months beginning in May 1974. One earlier sample from May 1973 was included for comparison in this analysis.

The small-sized fish were caught with the aid of a square "frame" that had single walls of plexiglass (Fig. 1). At first it encompassed an area of $1 \mathrm{~m}^{2}$ but this frame proved to be too unwieldy. Later on, the walls were shortened to $0.71 \mathrm{~m}$ yielding an area of 0.5 $\mathrm{m}^{2}$.

The frame was sunk roughly $10 \mathrm{~cm}$ into the mud flat. Afterwards the area was emptied of water, drawing it out by means of a pail, and pouring it through a hand-net. Thus the yield of small-sized fish could be quantified. After draining the interior of the frame the remaining fish were collected from the bottom and fixed in $4 \%$ formalin.

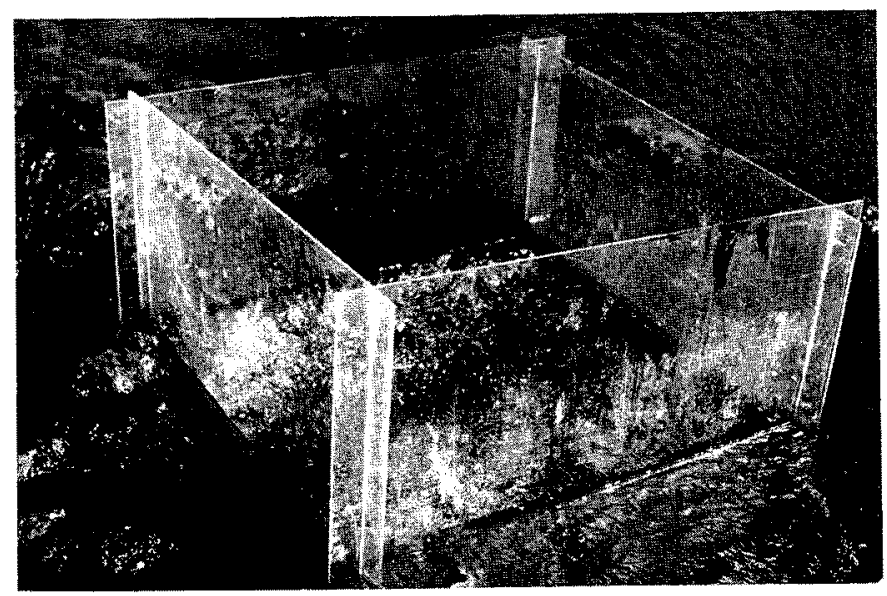

Fig. 1. Plexiglass frame for quantitative sampling of small-sized fish, comprising an area of $0.5 \mathrm{~m}^{2}$

Phytal samples, put into plastic bags under water, were fixed in $4 \%$ formalin. The main species was Fucus serratus with volumes between 66 and $295 \mathrm{~cm}^{3}$.

Benthos was sampled by means of a plexiglass frame $\left(10 \mathrm{~cm}\right.$ edge length; $0.01 \mathrm{~m}^{2}$ sampling area) from a sediment depth of $1 \mathrm{~cm}$ (cf. Giere, 1973). Finally, the $100 \mathrm{~cm}^{3}$ samples were fixed in $4 \%$ formalin. Since no parallel samples were taken, statistical calculations could not be made.

In the fishes sampled, body length and formalin wet weight were determined. For analysis of the ingested food, the guts were dissected and wet weight of the contents determined. The relation of gut content to fish wet weights yielded the fullness index (Hureau, 1969). The single components were counted and classified according to taxonomical or ecological units; algae and detritus were counted in relation to width of 
the mouth of the respective fish (Zander, 1979a, 1979b). The calculation of abundance, frequency, and ingested biomass was described earlier (Zander, 1979b).

The fauna of the phytal samples were grouped according to taxonomic units, counted, dried at $60^{\circ} \mathrm{C}$ until weight constancy, and weighed on a microscale. Dry weights of molluscs without shells were determined as follows: In the case of large bivalves and gastropods the soft body was separated from the shell and dry weighed; in the case of small molluscs, e.g. Hydrobia, the entire bodies were dry weighed, then made ash free $\left(6 \mathrm{~h}\right.$ at $\left.540^{\circ} \mathrm{C}\right)$ and weighed again; the difference of both figures yielded the dry weight of the soft body.

The benthal samples were stained with bengal-rose, suspended in a fluid containing water and phenole, and the fauna separated. Using three sieves, the following size groups were distinguished: $>400 \mu \mathrm{m}, 150-400 \mu \mathrm{m}$, and $<150 \mu \mathrm{m}$. The single components were counted and dry weight determined (see above). Only for foraminifers were the known dry weights of Ankar \& Elmgren (1976) used. Sieving of meiofauna yielded only an approach to size groups since not all organisms remained extended after fixing in formalin. All abundance and biomass values refer to an area of $1 \mathrm{~m}^{2}$.

\section{BIOTOPE}

The investigation site was previously described by Giere (1970) in his examinations of the meiofauna. The site was in the upper eulittoral zone at the end of a breakwater and was roughly 4 hours without water cover at low tide. The bottom consisted mainly of silt with a thin sand layer; occasionally small stones were present which made a slight overgrowth with Fucus serratus possible. At places with thick sand layers Zostera was present. At low tide many pools of up to $10 \mathrm{~cm}$ depth remained in the mud flat.

The range of water temperatures during the sampling days was $6^{\circ} \mathrm{C}$ in January to $16^{\circ} \mathrm{C}$ in September. Fluctuations of $6^{\circ} \mathrm{C}$ after strong solar radiation were possible during a day. Salinity was between 23 and $28 \%$; in cases where the shallow pools heated up, these values increased by $5 \% \mathrm{~S}$. On July $15^{\text {th }} 1974$ heavy rainfall caused a lowering of salinity to below $20 \%$.

\section{ABUNDANCE AND BIOMASS OF POTENTIAL FOOD ORGANISMS}

The analysis of benthos and of phytal samples shows a high diversity of potential food organisms.

The numbers of endo- and epifauna were greatest in April 1975 and lowest in September 1974 (Fig. 2). Harpacticoids and nematodes were always present, ranging between 72 and $93 \%$ of total abundance. Whereas harpacticoids dominated in September and November 1974, nematodes had the greatest proportions in the other months. Medium-sized nematodes reached $75 \%$ in January and April 1975, at other times small individuals dominated (Fig. 3).

The population density of harpacticoids was high in November 1974 and April 1975 , but low in September 1974, in spite of constituting $54 \%$ of the total benthos (Fig. 2). Similar to the situation in nematodes, the medium-sized harpacticoids dominated in January and April 1975, but at other times the small ones prevailed (disregarding nauplii) (Fig. 4). 


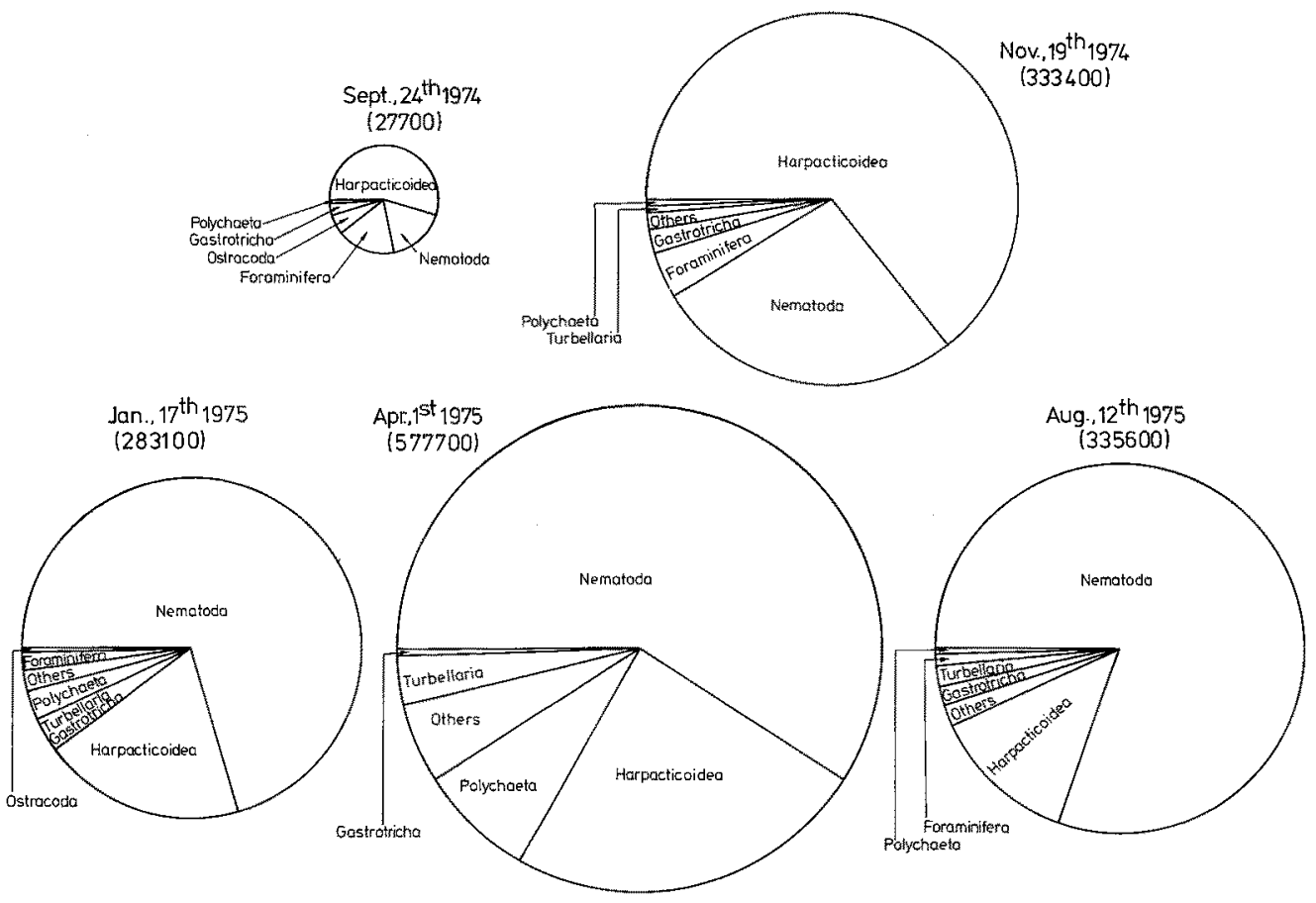

Fig. 2. Proportions of benthos organisms in relation to density. In parentheses: Total numbers of individuals $\mathrm{m}^{-2}$
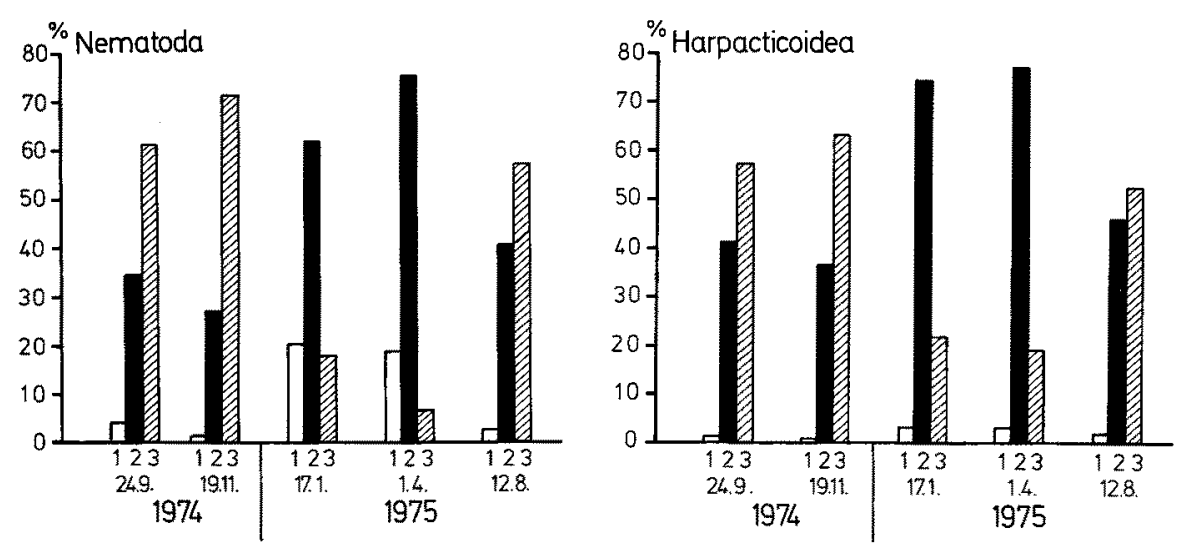

Fig. 3 (left). Size distribution of nematodes in the benthos samples. 1: $>400 \mu \mathrm{m}, 2: 400-150 \mu \mathrm{m}$, 3: $<150 \mu \mathrm{m}$

Fig. 4 (right). Size distribution of harpacticoids in the benthos samples. 1: $>400 \mu \mathrm{m}, 2: 400-150 \mu \mathrm{m}$, 3: $<150 \mu \mathrm{m}$ 


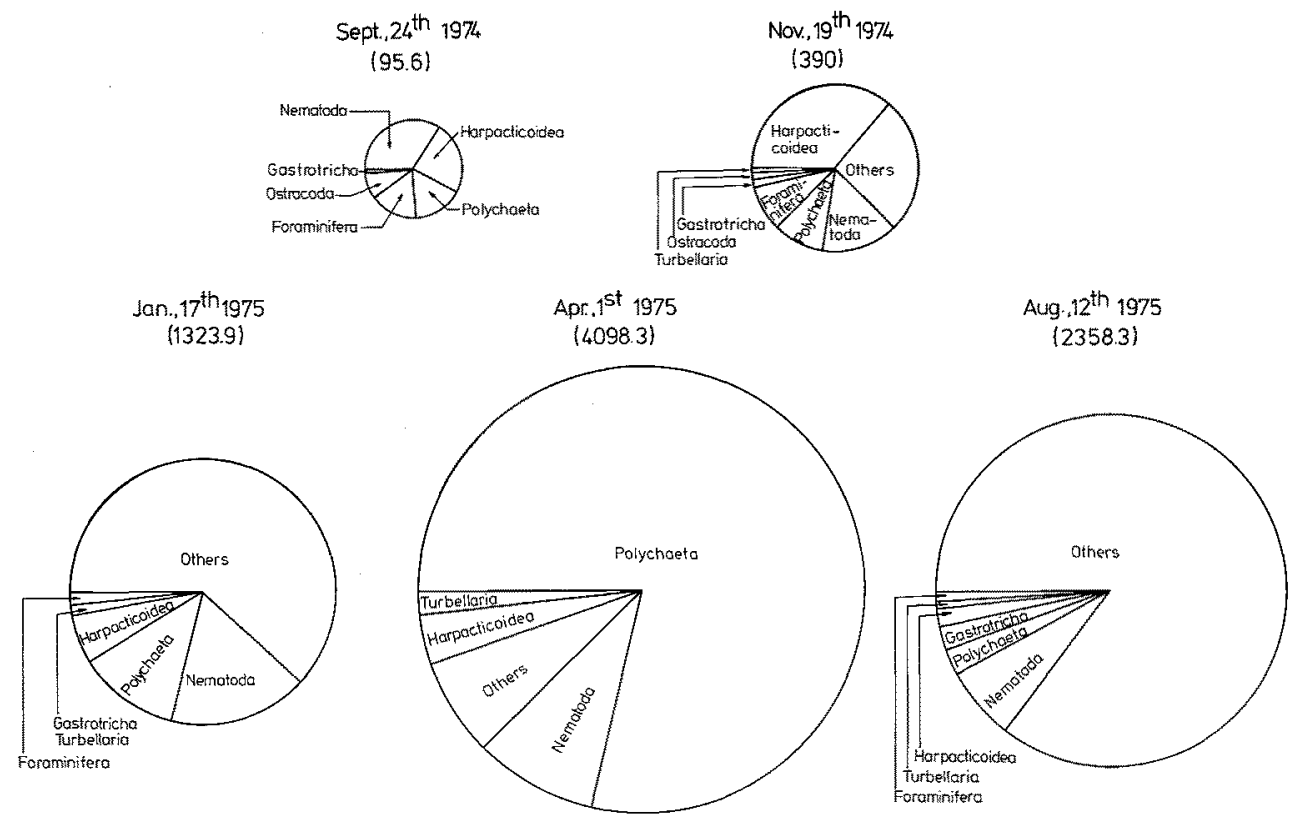

Fig. 5. Proportions of benthos organisms in relation to biomass. In parentheses: Total biomass $\left(\mathrm{mg} \mathrm{DW} \mathrm{m} \mathrm{m}^{-2}\right)$

Among the remaining components foraminifers were the most abundant group with proportions between 1 and $17 \%$ (September 1974) (Fig. 2). Polychaetes were most prevalent, $8 \%$, in April 1975, when total abundance was greatest (Fig. 2); $83 \%$ of this group were larger than $400 \mu \mathrm{m}$. Other benthos organisms - ostracods, turbellarians, gastrotrichs - as well as single macrofauna components - eggs, diverse larvae - play only a minor role and therefore are summarized as "rest fauna".

Variation in total biomass of benthos corresponds to the variation in abundance: Lowest values in September 1974 and highest values of about $4 \mathrm{~g} \mathrm{~m}^{-2}$ in April 1975 (Fig. 5). The proportion of nematodes was highest in September 1974 (34\%), whereas harpacticoids dominated in November 1974 (36\%) (Fig. 5). Individuals of more than $400 \mu \mathrm{m}$ size contributed an important part of biomass, among polychaetes as well as among the rest fauna (Fig. 5).

The total numbers of organisms from the phytal samples fluctuated strongly showing a minimum in May 1975 and a maximum in August 1975 (Fig. 6). The most prominent component in number were gastropods consisting mainly of Littorina littorea and $\mathrm{Hy}$ drobia sp. Their densities decreased continuously from May 1974 to April 1975, but had the highest values in August 1975 (Fig. 6). The proportion of bivalves - mainly Mytilus edulis - was only worth mentioning in September 1974 with $12 \%$ of the total fauna. In May 1975 gammarids (30\%) and Jaera albifrons (34\%) dominated, whereas in April 1975 Idothea sp. was the most abundant species (28\%). The isopods showed the highest densities in April and May 1975. Decapods - mainly Carcinus maenas - might be important only in summer, as indicated by high densities and proportions of $8 \%$ (July 

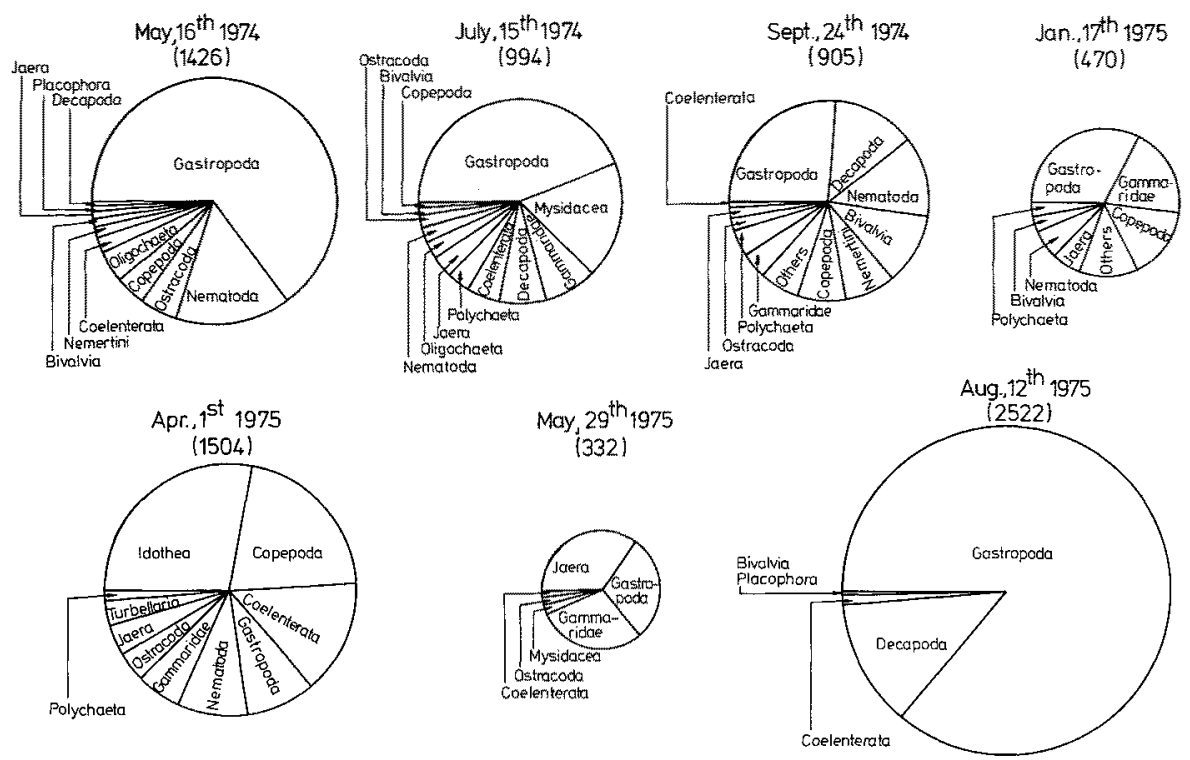

Fig. 6. Proportions of phytal organisms in relation to denstiy. In parentheses: Total numbers of individuals $\mathrm{m}^{-2}$

1974 ) and $14 \%$ (August 1975). The very vagile mysids were only notable in July 1974 (19 $\%)$. Single meiofauna components occasionally reached relatively high proportions, e.g. nematodes in May 1974 (15\%) or harpacticoids in April 1975 (21 \%) (Fig. 6).

The total biomass of the phytal-dwelling fauna rose from May to September 1974 , reaching $47 \mathrm{~g} \mathrm{~m}^{-2}$, and declined thereafter until May 1975; in August 1975, again, a very high value of $33 \mathrm{~g} \mathrm{~m}^{-2}$ was found (Fig. $7 \mathrm{~A}$ ). In this calculation molluscs dominated to a degree of 89 to $99 \%$, gastropods alone maximally reached $94 \%$. Only in September 1974, when total biomass was greatest, did the bivalves surpass the gastropods (Fig. 7A). Using this kind of differentiation decapods achieved at most only $6 \%$, whereas all other groups only appeared in April and May 1975. Therefore, these organisms were treated separately (Fig. 7B). Then, gammarids usually constituted the greatest proportion, which was highest in May 1975 at $94 \%$. Idothea sp. was present in considerable amounts, to a degree of $90 \%$ in April 1975. In May 1974 oligochaetes (31\%) and coelenterates (43\%) had some importance, as well as in September 1974 nemertines $(19 \%)$ and polychaetes (14\%). Meiofauna played, as expected, no role regarding biomass (Fig. 7B).

\section{ABUNDANCE AND BIOMASS OF FISH}

The fish species caught -- the common goby Pomatoschistus microps (Krøyer), the eel Anguilla anguilla L., the eelpout Zoarces viviparus (L.), and the threespined stickleback Gasterosteus aculeatus L. - showed the greatest abundance in September 1974 and lowest values in July 1974 and May 1975. In May 1974 only elvers of A. anguilla appeared, whereas the greatest density of fish colonization in September 1974 was caused only by $P$. microps. 

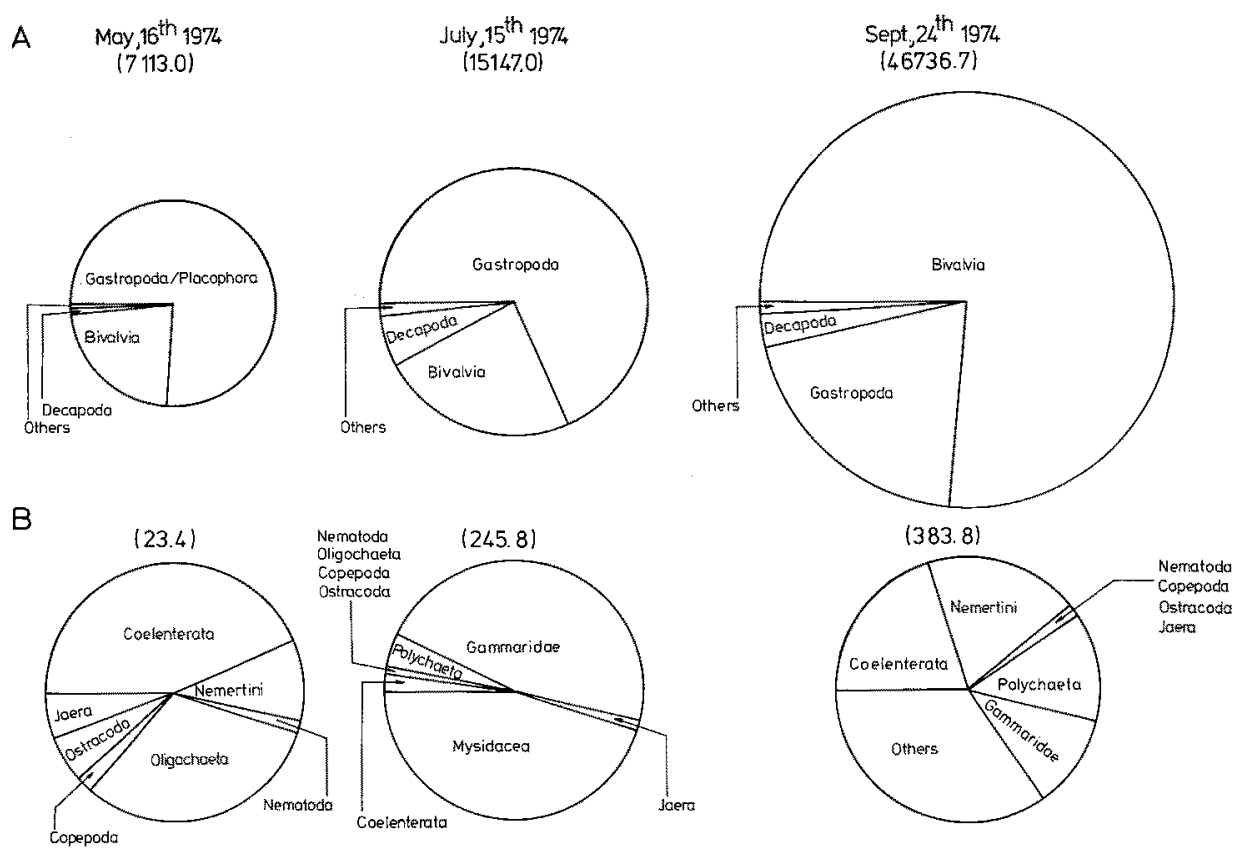

A Jan. $17^{\text {th }} 1975$

$$
\underset{(4507.6)}{\operatorname{Apr}, 1^{\text {st }} 1975}
$$

$$
\begin{gathered}
\text { May, } 29^{\text {th }} 1975 \\
(1106.9)
\end{gathered}
$$

Aug. $12^{\text {th }} 1975$
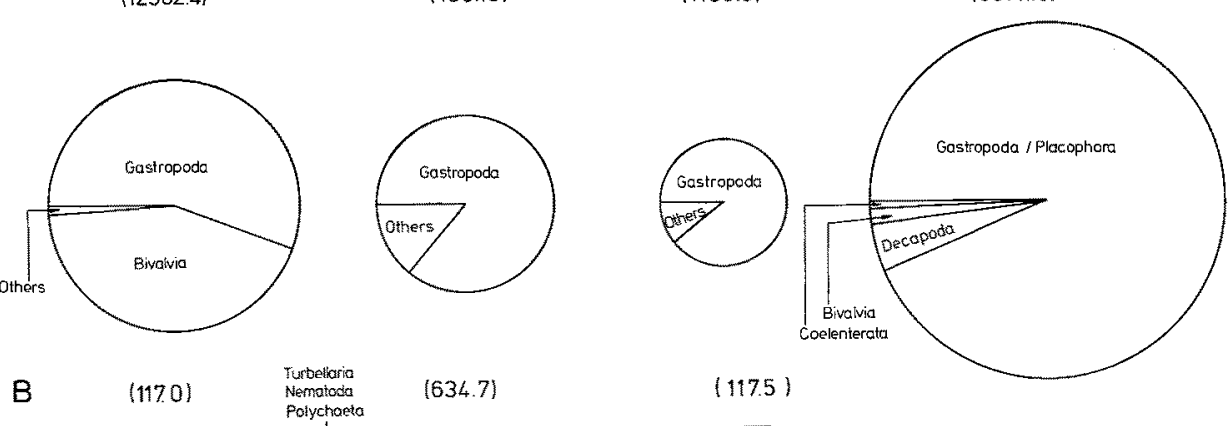

$[634.7]$

(117.5)

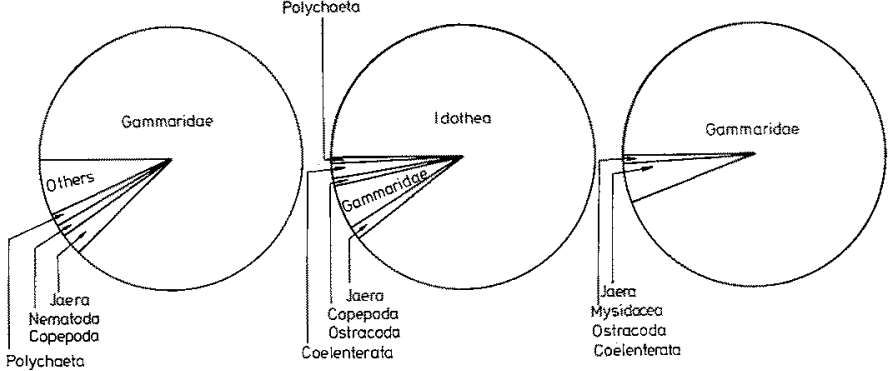

Fig. 7. Proportions of phytal organisms in relation to biomass. In parentheses: Total biomass ( $\mathrm{mg} \mathrm{DW} \mathrm{m}^{-2}$ ). Row A includes all components found, row B disregards molluscs 


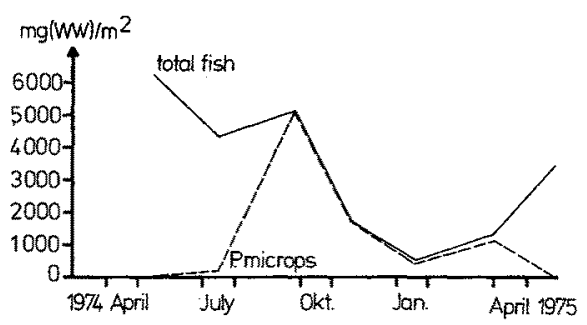

Fig. 8. Biomass of small-sized fish during the investigation time. Interrupted line: Pomatoschistus microps only

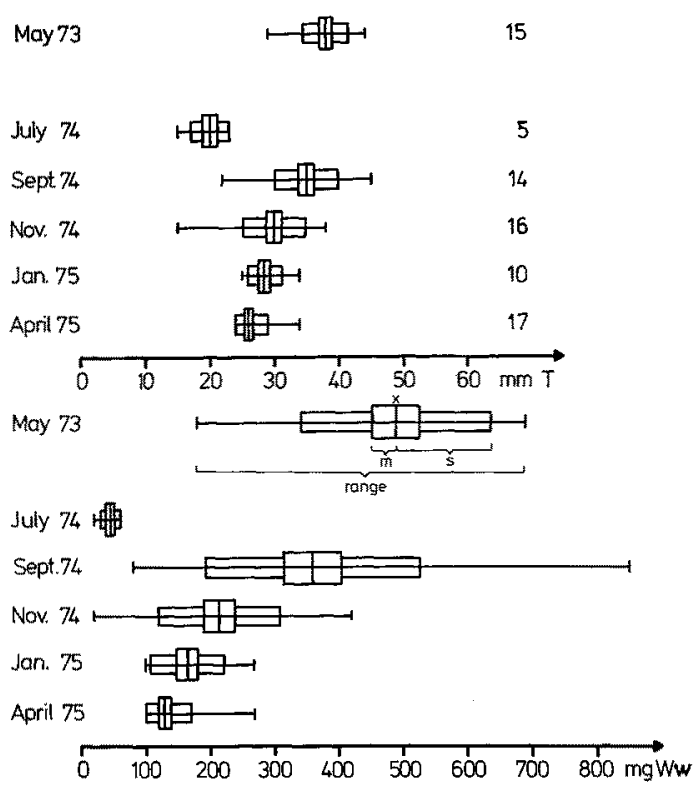

Fig. 9. Variability of size (above) and wet weight (below) of the caught Pomatoschistus microps. Right: Number of specimens. Explanation: $\mathrm{x}=$ mean value, $\mathrm{m}=$ mean error, $\mathrm{s}=$ standard deviation

The respective values of biomass (wet weight) make these results clearer (Fig. 8). The total biomass was high in spring and declined slowly towards summer but steeply in autumn and especially in winter. In the following spring, 1975, rest populations of gobies were present, which disappeared in May 1975 and were replaced by elvers.

Only for gobies were rough statements on the population structure possible (Fig. 9). The catch of July 1974 comprised juveniles which had apparently hatched at the beginning of the spawning period in May. After reproduction had finished in September, young individuals as well as yearlings were found, as the graph of size variability indicates (Fig. 9). From November to April 1975, a continual decline of mean size and weight was observed, which may lie in the continuous dying off of the oldest individuals. During the first investigation of the area in May 1973, yearlings of $P$. microps were also 
caught; however, these were absent in the same months of the years 1974 and 1975 (Fig. 9).

\section{FOOD INGESTED BY THE FISH}

\section{Fullness of guts}

The calculation of fullness indices (Hureau, 1969) of the P. microps catches yielded high values in summer, which declined to normal ones (about 1) from autumn to winter (Fig: 10). Again, an increase was found in April 1975 (Fig. 10).

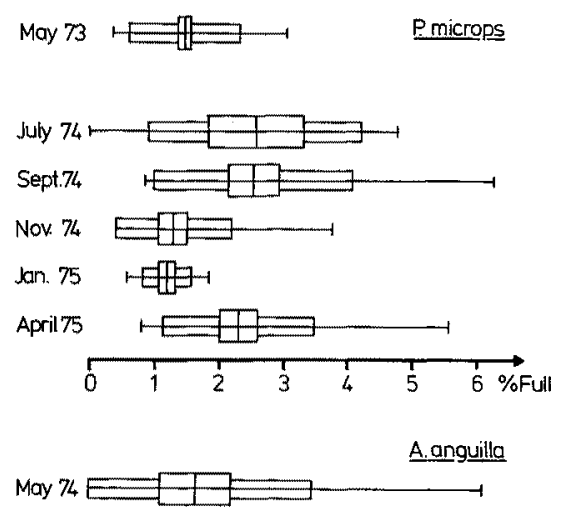

Fig. 10. Variability of fullness indices of the investigated Pomatoschistus microps and Anguilla anguilla. Further explanations see Fig. 9

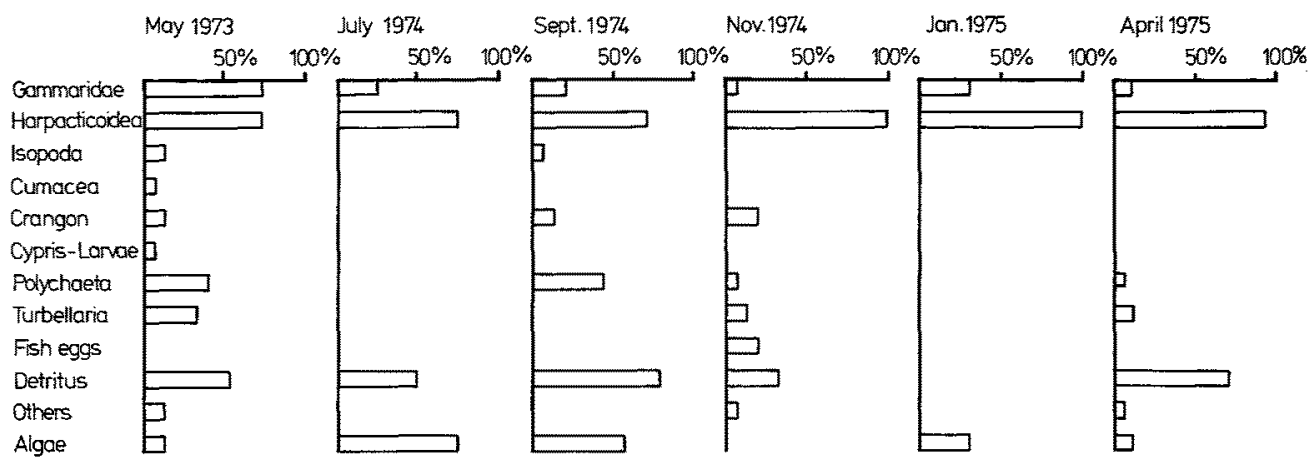

Fig. 11. Frequency of occurrence of food organisms in Pomatoschistus microps during the investigation time

Among eels, only the catch of May 1974 was analyzed; the fish showed high degrees of variability and a high proportion of empty guts (Fig. 10). The only two eelpouts from January and April 1975 had indices of 2.9 and 4.2, respectively. The catch of four Gasterosteus aculeatus from May 1973 yielded values between 3.0 and 7.8. 


\section{Frequency of occurrence}

In every sample a high percentage of $P$. microps had preyed on harpacticoids (Fig. 11); gammarids were also regularly present but mostly at low frequencies. Relatively many gobies had ingested detritus and algae which, however, were absent in some catches. All other components were not fed on regularly (Fig. 11).

The question of the preferred feeding habitat of $P$. microps was answered by the method of summing up the respective components. By this, epibenthos proved to be the main food source (100\% in every sample) and phytal fauna played an important role (100-20\%), whereas plankton organisms were absent.

The analysis of the elvers caught in May 1974 showed a wide variability of prey organisms among which Mytilus and turbellarians were the most frequent ones.

\section{Abundance analysis}

After analysing the numbers of all ingested components of a sample, the great proportion of harpacticoids (87-95\%) in the guts of $P$. microps is conspicuous (Fig. 12). Algae and detritus, which were fed on relatively frequent (Fig. 11), were present only in small percentages by abundance. The same is valid for gammarids (Fig, 12). The sample of May 1973 contained, contrary to those of the years 1974 and 1975 , only $68 \%$ harpacticoids but a relatively large number of macrofauna components. Considering these results, it can be concluded that $P$. microps did not change its feeding habits during ontogeny, since in September (high mean size) as well as in July 1974 (low mean size) roughly equal parts of macro- and meiofauna were fed on, respectively (Fig. 12).

The food of the other species is less exactly interpretable, because large series are absent. In spite of this, it was apparent that the elvers fed on great parts of harpacticoids in May 1974, whereas the larger specimens of July 1974 ingested exclusively gammarids (Fig. 12). The two eelpouts caught in January and April 1975 preyed on identical food, which consisted mainly of harpacticoids (Fig. 12). The same statement is valid for the stickleback catch of May 1973.

\section{Biomass of food}

For the calculation of the ingested biomass, the mean dry weights (DW) of the potentially available food organisms were used; these were applied to the components found in the guts. Though this method allows only an approximation of the real conditions, its use is more exact than that of weighing the damaged and differently digested components directly from the guts.

The relation of ingested food to total fish biomass does not reflect the results got by means of the fullness index (Fig. 13). In spring, biomass was low but in autumn very high. Considering single components by weight yields results, differing from those attained by abundance analysis (Fig. 14). Organisms of the macrofauna, especially gammarids, dominate by far, whereas harpacticoids, which prevailed in number, played an inferior, and to some extent an unimportant role. Furthermore, it is remarkable that (1) Crangon crangon was important as food for P. microps in autumn; (2) Jaera albifrons was a great energy supplier for $P$. microps and, especially, $Z$. viviparus in spring; (3) Mytilus constituted more than $90 \%$ of biomass for the young $A$. anguilla in May 1974 (Fig. 14). 
May $16^{\text {th }} 74$

Pmicrops
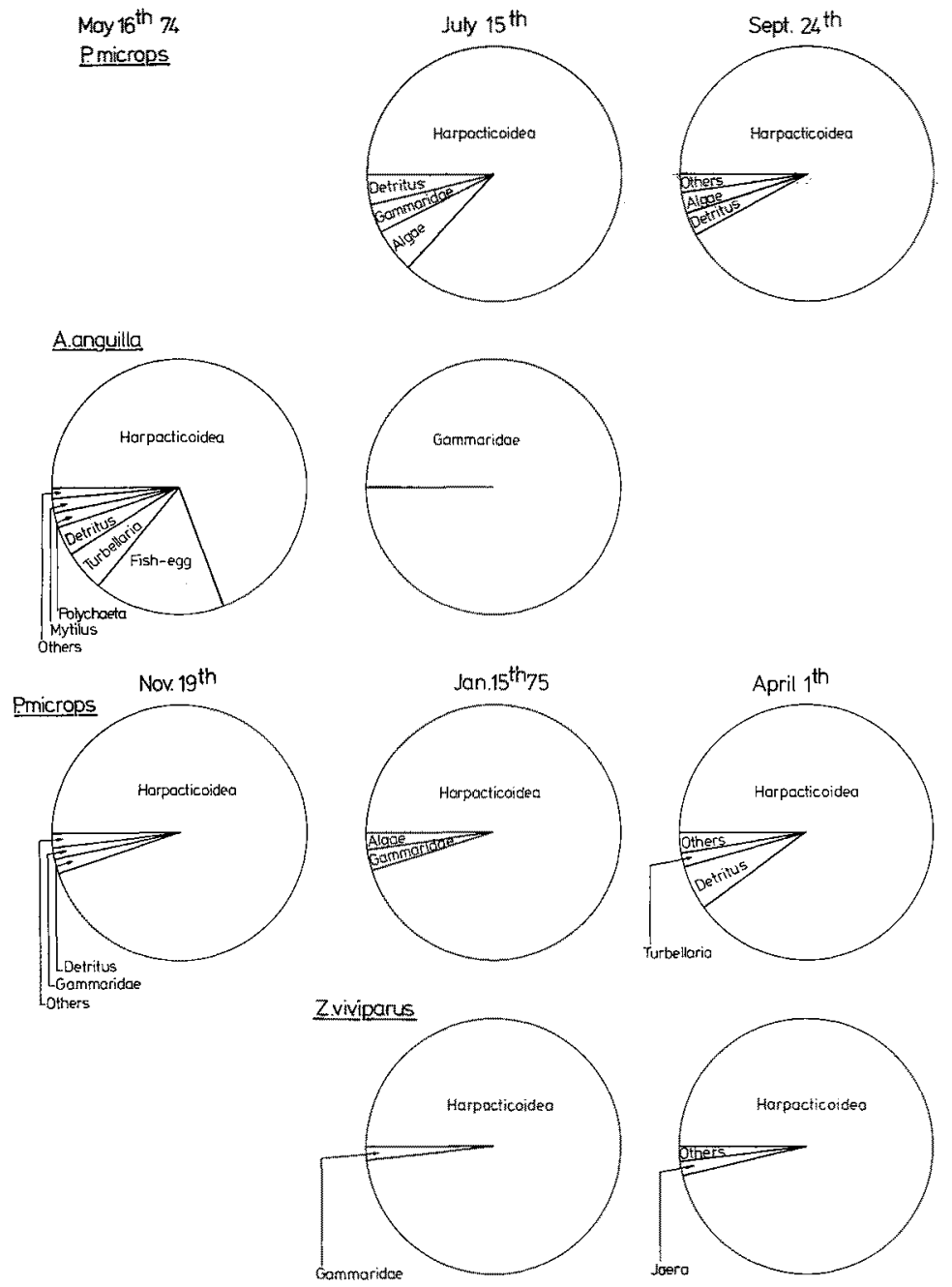

Fig. 12. Abundance analysis (numbers) of the food organisms in Pomatoschistus microps, Anguilla anguilla, and Zoarces viviparus during the investigation time

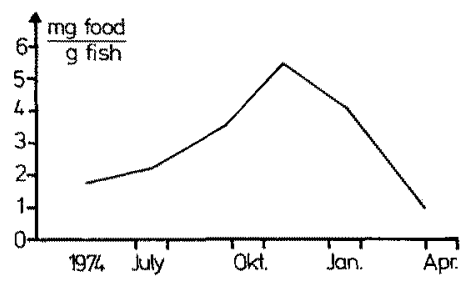

Fig. 13. Relationship between weights of ingested food (DW) and fish (WW) during the time of investigation 

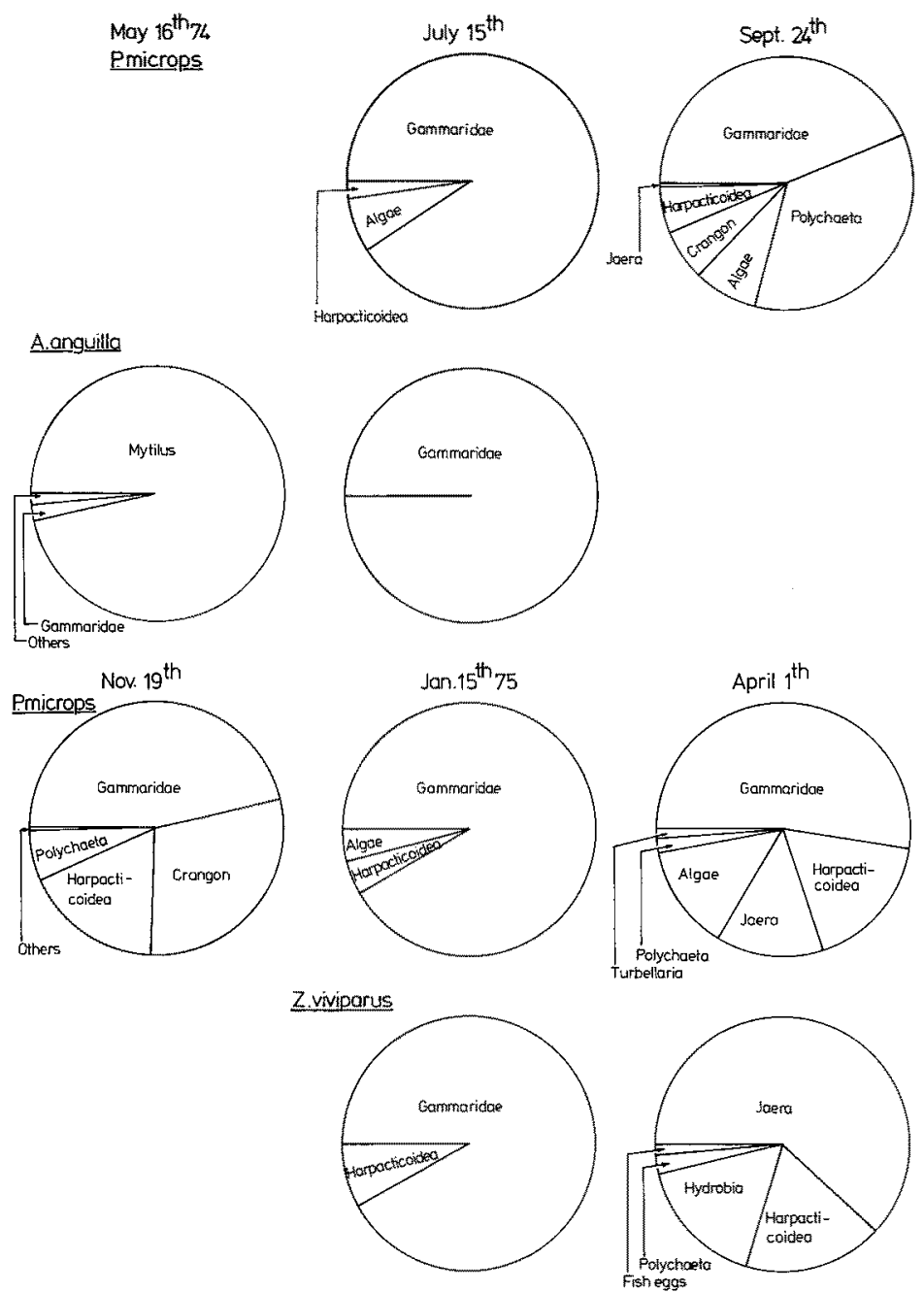

Fig. 14. Proportion of food biomass in Pomatoschistus microps, Anguilla anguilla, and Zoarces viviparus during the time of investigation

The total biomass ingested by all fish decreased slightly from May to July 1974 but increased steeply in September; during winter very low values were found. Considering the biomass of distinct food components separately, their relative significance becomes evident (Fig. 15). Most gammarids were preyed on in July, while the highest biomass of harpacticoids was found in September 1974.

The latter result coincides directly with the abundance of harpacticoids in the benthos samples. Therefore, the high food uptake of these organisms in September probably achieved a supply of them which was more than $50 \%$ below that of the following months (Fig. 16). Regarding gammarids, for example, in July 1974 a high supply as well as a high feeding rate were found (Fig. 16). Together with a decrease in 


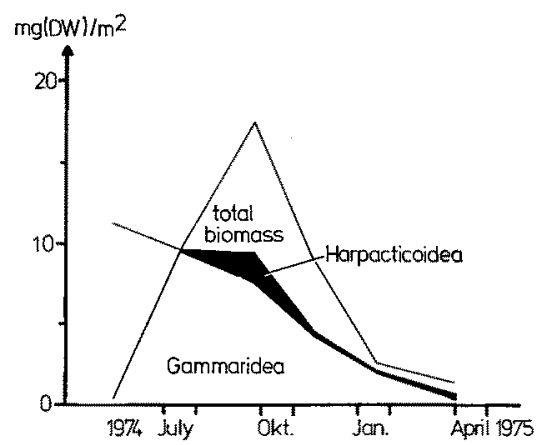

Fig. 15. Biomass of food (gammarids, harpacticoids and other components) ingested by the fish during the time of investigation
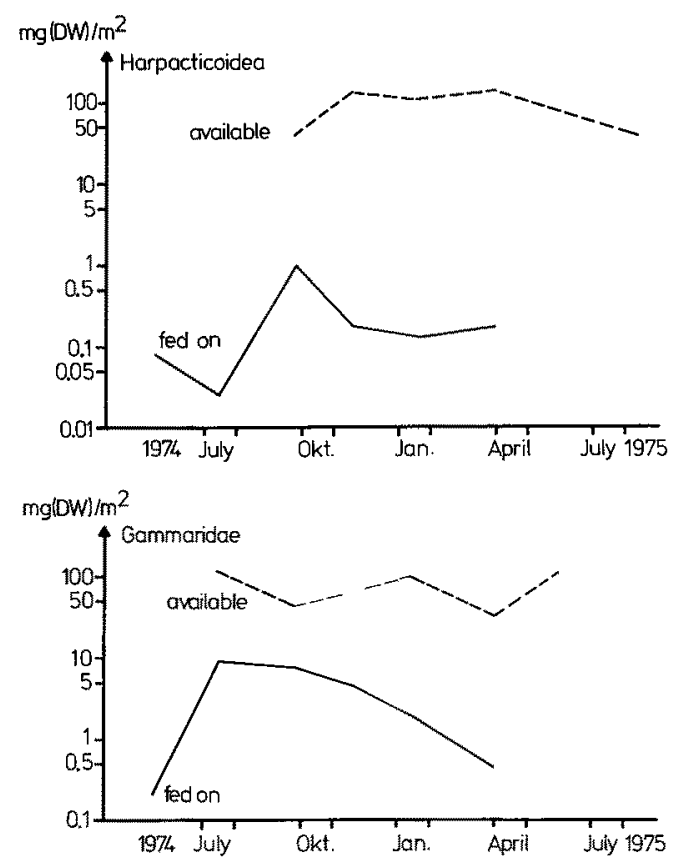

Fig. 16. Relationship between available and ingested harpacticoids (above) and gammarids (below) during the time of investigation

food uptake, only irregular fluctuations of gammarid supply were found in the next samples.

\section{DISCUSSION}

\section{Fluctuation of potential food organisms}

Abundance and biomass of benthos show minima in September 1974 and maxima in April 1975 (Figs 2, 5). Density and size group variability of nematodes, harpacticoids (Figs 3,4), and polychaetes, especially in April 1975, are responsible for this phenome- 
non. The fluctuations of nematode abundance in the Keitum mud flat were confirmed by studies in other eulittoral and sublittoral biotopes (Möller et al., 1976; Skoolmun \& Gerlach, 1971). Regarding harpacticoids, Möller et al. (1976) found situations similar to that on Sylt island in the nearshore sublittoral zone. The so called rest fauna which was found to be insignificant in number (Fig. 2) may constitute a great part of benthos biomass (Fig. 5); this mostly depends on specimens which were larger than $400 \mu \mathrm{m}$.

The abundance analysis of organisms from the phytal layer did not show clear annual fluctuations. This might be due to the difficulty in collecting all vagile macroand meiofauna, especially mysids, isopods, gammarids, and decapods, or to the habits of some intertidal species, respectively (Reise, 1977). Our results were confirmed by Gründel (1976) who studied samples from shallows of the Baltic Sea. Indeed, biomass dynamics of phytal organisms from Keitum (Fig. 7) do not correspond to the abundance (Fig. 6) but are influenced by the annual production of mollusc biomass, which account for 89-99 \% of total biomass. Worthmann (1975) demonstrated a similar annual cycle of mollusc biomass in the Kiel Bight with high values in summer and autumn, low ones in winter and spring. The abundance fluctuation of decapods is correlated with the biomass cycle and is dependent on the migrations of Carcinus maenas (Muus, 1967; Reise, 1977). After hibernating in the sublittoral zone the young crabs migrate into the mud flat in July; in September they start to emigrate into deeper waters. The isopod stocks are subject to strong fluctuations (Muus, 1967); this author found the greatest densities in late summer and autumn and therefore supported the assumption of Howes (1939), which correlated isopod density with the annual course of the aufwuchs on the great algae. This assumption could not be confirmed in the Keitum mud flat. The reason for this finding may lie in the tidally dependent feeding migrations of isopods. Similar behaviour is known of gammarids and mysids (Reise, 1977). Mysids showed high percentages of total abundance and biomass in the Keitum mud flat. A massive occurrence of these organisms was also observed by Zander (1979a) on the Helgoland rock flat in August.

\section{Fluctuation of fish}

During the investigations at Keitum mud flat only a few fish species were found: Pomatoschistus microps, elvers of Anguilla anguilla, Zoarces viviparus, and, exclusively in May 1973, Gasterosteus aculeatus. The elvers only occurred in spring but were present in masses on their way to the river estuaries. A single specimen was caught in July 1974, the size of which indicated it had delayed its migration into fresh water. In this month common gobies appeared for the first time, represented only by young specimens, whereas one year old ones remained in the sublittoral zone for spawning. Not until September did the catches represent a mixture of young and one year old specimens. Since only few common gobies survive the second winter, the successive decease of the elder specimens will have caused the continual decrease of mean size or weight in the following samples. In May 1975, all gobies had emigrated for spawning into the sublittoral zone.

Only single specimens of eelpouts were caught in January and April 1975; therefore we assume that this species migrates only rarely into the eulittoral zone. The role of Gasterosteus aculeatus individuals in the Keitum mud flat is not yet clear, since they were caught only in May 1973. 
With the exception of Zoarces viviparus, all species are also found in fresh water. All of them are euryhaline fish with distinct seasonal migrations from the sea into fresh water or vice versa (Hennig \& Zander, 1981). Juveniles of P. microps invade the rivers in late summer, as was observed in British waters (Miller, 1964; Kunz, 1969) and in the Elbe river (Hennig \& Zander, 1981). When temperatures decrease in late autumn, they migrate down the rivers into deeper waters of the sea. The young $G$. aculeatus swim from the spawning grounds in fresh waters into the sea and return when 2 years old for spawning. The young $A$. anguilla invade the rivers in spring and, after some years, migrate back to the Sargossa Sea for spawning (Müller, 1975). The eelpout, on the other hand, is a genuine marine species which also inhabits brackish waters.

According to these results, the extensive similarities between the small-sized fish fauna in the rest pools of a marine and of a fresh water mud flat become evident. Besides $G$. aculeatus, $P$. microps, and $A$, anguilla, the fresh water mud flat also included Pungitius pungitius (Hennig \& Zander, 1981), which regularly migrates into brackish water (Münzing, 1966). Only during high tide were the mud flat biotopes invaded by genuine marine or fresh water fish, respectively.

The mud flats, therefore, are exclusively feeding and nursery, probable hiding places but not spawning grounds for the studied fish. The latter statement is valid for $P$. microps in marine mud flats as well for the sticklebacks in fresh water ones.

\section{Qualitative prey-predator relationships}

By classifying the ingested food according to distinct microhabitats with regard to its respective origin, only slight differences are found between the investigated fish species. $P$. microps clearly preferred epibenthos to phytal species, whereas suprabenthic components were absent. During the course of time a continual decrease of food items originating from the phytal zone was found in this species. In A. anguilla phytal-fauna dominated over epibenthos; in G. aculeatus from May 1973 suprabenthic organisms (mysids) were also present. Therefore, differences in results from other investigation sites are evident. In the Fährmannsand mud flat of the Elbe river $A$. anguilla had mainly fed on endobenthos which consisted predominantly of oligochaetes, whereas $G$. aculeatus and, to a lesser degree, P. microps preferred plankton (Hennig \& Zander, 1981); epibenthos organisms played no role in the food of these fish. On a stony ground in the Baltic Sea, on the other hand, suprabenthos was seldom ingested by $P$. microps which preferred phytal-living fauna and epibenthos there (Zander, 1979b).

Regarding single food components, two, found in P. microps from Keitum, are notable: (1) Crangon crangon inhabiting the epibenthal layer was fed on regularly but not abundantly. This species was found with a relatively high biomass in common gobies from Scotland (Healey, 1972) and from the mouth of the Elbe river (Kühl, 1972). (2) Algae were not found in the previous investigations of $P$. microps guts, but were present in the related $P$. pictus (Zander, 1979a). In Keitum, algae were also ingested regularly but in low biomass. Presumably they were fed on, only by chance, together with small vagile organisms.

On the other hand, in the $P$. microps from Keitum, components are absent which were frequently preyed on by specimens at other sites, such as Corophium (Healey, 
1972), chironomid larvae and Idothea (Zander, 1979b). The reason may lie in the absence or rare occurrence of the potentially available food.

\section{Quantitative prey-predator relationships}

The most important nutritional component with regard to weight was gammarids in all investigated fish of the Keitum mud flat. The next important foods, with annual fluctuations, were polychaetes, Crangon, or harpacticoids in P. microps. Only the elvers of A. anguilla had ingested great proportions of Mytilus in May 1974, whereas, in Z. viviparus, Jaera dominated in April 1975. The harpacticoids, which were dominant in number but unimportant in biomass are an indicator for the great feeding activity of $P$. microps. This result is in agreement with other investigations regarding this species (Casabianca \& Kiener, 1969; Groth, 1978; Zander, 1979b; Hennig \& Zander, 1981; Schmidt-Moser \& Westphal, 1981). In G. aculeatus plankton copepods frequently dominated (Hynes, 1950; Hennig \& Zander, 1981).

During the course of the year the biomass of ingested food was greatest in summer and autumn but lowest in winter. No correlation was found between food supply and density or biomass of small-sized fish which was greatest in spring and summer. A very great predatory activity was found in September 1974 (Fig. 15). Temperatures decreased after September to $7^{\circ} \mathrm{C}$ and reduced feeding activity. But in the November catch a great part of young fish was still present which apparently needed a high energy supply for growth.

In September 1974, when density of $P$. microps was greatest, a high feeding rate on harpacticoids coincided with an evidently reduced supply of these organisms. This phenomenon may be due to grazing effect but other explanations are also possible. In the fresh-water mud flat Fährmannsand (Elbe river), cyclopoids and harpacticoids decreased at the time when young $P$. microps immigrated (Hennig \& Zander, 1981). This was also confirmed for the Baltic Sea fjord Schlei (Schmidt-Moser \& Westphal, 1981). Reise (1979), on the other hand, found $P$. microps to have no influence on meiofauna during cage experiments.

The biomass ingested by small-sized fish in the Keitum mud flat was highest in

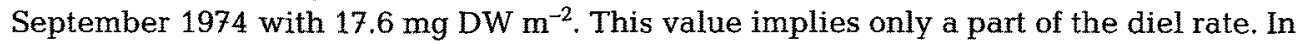
$P$. microps the digestion time of food is unknown but was found in the related Gobiusculus flavescens to be about 3 hours (Berg, pers. comm.). Based on this result one may expect a turnover rate of roughly $70 \mathrm{mg} \mathrm{DW} \mathrm{m}^{-2} \mathrm{~d}^{-1}$ since the fish are active only during the day. As the benthal and phytal layers offer a food biomass of $480 \mathrm{mg} \mathrm{DW} \mathrm{m}^{-2}$ (without molluscs) this means that almost one seventh might be turned over by small, bottom fish in a day.

Acknowledgements. We are indebted to A. Dowling, H. Lachnit, D. Lorenzen, and L. SeitzHildebrand for technical help and to $M$. Hänel for drawing the figures. The "Sonderforschungsbereich $94^{\prime \prime}$ of the University Hamburg supported the field studies by travel grants, the Deutsche Forschungsgemeinschaft by grants to the first author (Za 44/4). 


\section{LITERATURE CITED}

Ankar, S. \& Elmgren, R., 1976. The Baltic macro- and meiofauna of the Askö-Landsort-Area (Northern Baltic Proper). - Contr. Askö Lab. 11, 1-115.

Casabianca, M. L. \& Kiener, A., 1969. Gobiidés des étangs Corses: Systématique, écologie, régime alimentaire et position dans les chaînes trophiques. - Vie Milieu (A) 20, 611-634.

Giere, O., 1970. Untersuchungen zur Mikrozonierung und Okologie mariner Oligochaeten im Sylter Watt. - Veröff. Inst. Meeresforsch. Bremerhaven 12, 491-529.

Giere, O., 1973. Oxygen in the marine hygropsammal and the vertical microdistribution of oligochaetes. - Mar. Biol. 21, 180-189.

Groth, V., 1978. Nahrungsbeziehungen von Kleinfischen im Elbemündungsbereich. - Dipl. Arbeit, Hamburg, $60 \mathrm{pp}$.

Gründel, E., 1976. Qualitative und quantitative Untersuchungen an einem Ókosystem "ZosteraWiese" vor Surendorf (Kieler Bucht, Westliche Ostsee). - Rep. SFB 95, Univ. Kiel 18, 1-157,

Healey, M. C., 1972. On the population ecology of the common goby in the Ythan estuary. - J. nat. Hist. 6, 133-145.

Hennig, R. \& Zander, C. D., 1981. Zur Biologie und Nahrung von Kleinfischen des Nord- und Ostsee-Bereichs. III. Die Besiedlung eines Süßwasserwatts der Elbe durch euryhaline Fische. Arch. Hydrobiol. (Suppl.) 43, 487-505.

Howes, N. H., 1939. Observations on the biology and postembryonic development of Idothea viridis from New England Creek, south east Essex. - J. mar. biol. Ass. U. K. 23, 279-310.

Hureau, J. C., 1969. Biologie comparée de quelques poissons antarctiques (Nothotheneidae). - Bull. Inst. océanogr. Monaco 68, 1-250.

Hynes, H. B. N., 1950. The food of fresh-water sticklebacks (Gasterosteus aculeatus and Pygosteus pungitius), with a review of methods used in studies of the food of fishes. - J. Anim. Ecol. 19, 36-58.

Kühl, H., 1972. Hydrography and biology of the Elbe estuary. - Oceanogr. mar. Biol. 10, 225-309.

Kunz, Y., 1969. Salinity preference and salinity tolerance of the katadromous teleost Pomatoschistus (Gobius) microps Krøyer. - Proc. R. Ir. Acad. (B) 68, 77-88.

Miller, P. J., 1964. The biology of the goby Pomatoschistus microps. - Rep. Challenger Soc. 3, (16), $42-43$.

Möller, S., Brenning, U. \& Arlt, G., 1976. Untersuchungen über die Meiofauna des Barther Boddens unter besonderer Berücksichtigung der Nematoden. - Wiss. Z. Univ. Rostock 25, 271-281.

Müller, H., 1975. Die Aale. Ziemsen, Wittenberg-Lutherstadt, $200 \mathrm{pp}$.

Münzing, J., 1966. Variabilität, Verbreitung und Okologie von Pungitius pungitius (L.) (Pisces) in Norddeutschland. - Faunist.-ökol. Mitt. 3, 36-50.

Muus, B. J., 1967. The fauna of Danish estuaries and lagoons. - Meddr Danm. Fisk,-og Havunders. (N. S.) $5,1-316$.

Reise, K., 1977. Predator exclusion experiments in an intertidal mudflat. - Helgoländer wiss. Meeresunters. 30, 263-271.

Reise, K., 1979. Moderate predation on meiofauna by the macrobenthos of the Wadden Sea. Helgoländer wiss. Meeresunters. 32, 453-465.

Schmidt-Moser, R. \& Westphal, D., 1981. Predation of Pomatoschistus microps (Krøyer) and $P$. minutus (Pallas) (Gobiidae, Pisces) on macro- and meiofauna in the brackish fjord Schlei. Kieler Meeresforsch. (Sonderbd) 5, 471-478.

Skoolmun, P. \& Gerlach, S. A., 1971. Jahreszeitliche Fluktuationen der Nematodenfauna im Gezeitenbereich des Weser-Ästuars (Deutsche Bucht). - Veröff. Inst. Meeresforsch. Bremerhaven $13,119-138$.

Worthmann, H., 1975. Die Makrobenthos- und Fischbesiedlung in verschiedenen Flachwassergebieten der Kieler Bucht (Westliche Ostsee). Dipl. Arbeit, Kiel, 141 pp.

Zander, C. D., 1979a. On the biology and food of small-sized fish from the North and Baltic Sea area. I. Investigations on Pomatoschistus pictus (Malm) (Gobiidae) from Helgoland. - Zool. Anz. 202, 413-424.

Zander, C. D., 1979b. On the biology and food of small-sized fish from the North and Baltic Sea areas. II. Investigation of a shallow stony ground off Møn, Denmark. - Ophelia 18, 179-190. 